\title{
GOTHIC ROOTS: BROCKDEN BROWN'S WIELAND, AMERICAN IDENTITY, AND AMERICAN LITERATURE
}

\author{
Renata R. Mautner Wasserman \\ Wayne State University
}

\begin{abstract}
Charles Brockden Brown's Wieland (1798), one of the first novels by an American author set in the newly formed United States, and dealing with American topics, is generally classed as a "Gothic" novel and read as exploring issues of national identity. The Gothic form, popular in English literature, where it gave sensationalistic treatment to matters of gender, class, national identity and religious affiliation, proved adaptable to conditions overseas. Wieland, however, is less sanguine about the success of the nation-building and independence-achieving enterprise than other, later, novels of American national identity.
\end{abstract}

Keywords: Charles Brockden Brown, Wieland, Early American Literature, Gothic, American identity.

Charles Brockden Brown's Wieland, published in 1798, is one of the first "American" novels, such works defined as having an American author and American subject-matter. ${ }^{1}$ It is set in

\begin{tabular}{|l|l|l|l|l|}
\hline Ilha do Desterro & Florianópolis & n62 & p. 197- 217 & jan/jun 2012 \\
\hline
\end{tabular}


Pennsylvania, tells the story of several horrific events, the causes of which are mysterious and possibly supernatural, and rehearses matters of identity (personal and national) as well as of morality and rationality, religious belief and science that are often subsumed in the question of identity. The Gothic, in turn is a genre agreed to be particularly appropriate for the expression of cultural, as well as psychological anxieties of a subterranean kind, hard to acknowledge in other ways. Thus, rather than being seen as a self-indulgent genre that caters to a taste for sensation and for the irrational, it is now generally recognized as doing what Jane Tompkins has called "cultural work." 2 These works distill, as she sees it, "the fears and dangers uppermost in the society of [the] time, especially as that society appeared to women," ${ }^{3}$ though, as Scott Simpkins notes, given the number of male writers of the Gothic and the "ubiquitous male characters who populate the genre," we should remember that the genre also deals with "men and their often troubled versions of masculinity" (122). But these are only two of the many inspirations for Gothic-driving anxiety: national or ethnic identity and perceived threats to it, territorial claims and relations to the natural world, class mobility, rights and problems of inheritance, and all kinds of power relations between genders, classes, generations, and political positions underlie the sensationalistic superstructure of Gothic plots.

Wieland is generally described as a Gothic text; Brown is said to have had a "Gothic imagination," ${ }^{4}$ and the plot to be based on a "Gothic" event: the crime of a man who, claiming to have acted in obedience to the voice of God, had killed his wife and children some two years before the publication of the novel..$^{5}$ But Wieland, which, in fact, is seen by many as adapting the wildly successful English Gothic to American conditions, is an odd example of the genre, and 
can also be understood as a relatively straightforward approach to the problems and fractures in the new American republic. In that view, its Gothic elements might not suffice to class it with either the terror novels of Ann Radcliffe, like The Mysteries of Udolpho (1794) and The Italian (1797), or with Matthew Lewis's horror novel The Monk (1796). If, however, it is agreed that the mysterious events it recounts (some explained in the end, as is demanded of the Gothic of terror, some not, as in the Gothic of horror); the menacing locations (houses with unknown passages, hilltops of difficult access, woods and marshes, caves and precipices); the preoccupation with patriarchal power exercised over women and children; the fascination with, and distrust of, current scientific knowledge, are sufficient to classify the work as Gothic, then the next order of business is to figure out how all these elements coalesce to characterize this very early novel of American nationhood. And then it will be necessary to see how the novel's concentration on identity, personal and national, uses these Gothic elements and creates with them a fiction of national identity.

As Teresa Goddu points out, in giving fictional (and, maybe manageable) form to anxieties current at the time, the Gothic resorts to sensationalist plots, calling up situations of extreme danger and fears that can be considered irrational, though they can also be confirmed by unlikely events. In effect, the irrational, or super-rational are almost obligatory in the Gothic. Goddu classifies Wieland without doubt as a Gothic novel, but her caution that any novels from that genre are intricately and sometimes rather complexly interested in the historical situation where they arise, also justifies David Lee Clark's as well as Bill Christophersen's contentions that what we are looking at is a straightforward working through of historical material, from the anti-German xenophobia common 
in Philadelphia at that period, and based on the large numbers of German immigrants then entering the country, to specific instances of provocation like that of the pastor who proposed creating such a strong, isolated German community that the Anglos would just leave and grant them the territory, with its own schools, churches, and government, all functioning in German. Benjamin Franklin himself delivered some anti-German pronouncements, afraid that those immigrants would take over and displace the English stock that should be the foundation of the new nation. ${ }^{6}$

Gothic or not, in Wieland Brown approaches the cultural landscape of his time-as well as the physical one, as he explores the way in which his characters occupy the American land, and Christophersen gives an extensive account of the political anxieties floating about at the time of the novel's publication. In 1789 the new Republic was undergoing a number of simultaneous crises: France, its old ally in the Revolutionary War, was having its own Revolution, whose extreme doctrines seemed a threat to American stability; France was also engaged in territorial ambitions on the North American continent, which gave rise to the French and Indian wars. England, the former colony's old colonial master had declared war on the French, but was also raiding American ships and impressing its sailors for its wars. In addition, there were serious political disagreements about the kind of economic development that would be encouraged in the new nation, pitting an agrarian population against those engaging in the beginnings of an industrial development for the country. The influx of immigrants raised further questions about the make-up of the new nation's population, while at the same time, and sometimes in relation to those same immigrants, arguments about the predominance and influence of religion, in its different manifestations, divided the public. 
As mentioned, some of these arguments would play out in the Pennsylvania where Wieland is set, given thelarge number of Germans who had established themselves in Philadelphia and its environs. Some of these immigrants were, like the Wielands at the center of the novel-or like the Quaker parents and ancestors of Brockden Brown himself-followers of a variety of pietistic denominations, several derived from the Albigensians, Cathari, Camissards, whose ideas, though cruelly persecuted from the Middle Ages on, had not been suppressed, and survived, for instance, among the Moravians who settled in the region. ${ }^{7}$ Yet, for all that it is "American," the novel begins and ends in Europe, where the elder Wieland is born, marries, acquires his unorthodox religious beliefs, and decides to emigrate to America, attracted by the religious tolerance he hears reigns there. And to Europe, as we learn, his daughter later returns. As is characteristic, then, of works of American national identity, Wieland probes the relation between the European complex of ideas by which the desire for independence from Europe justifies itself and the implementation of these ideas on American soil, yet it also questions the composition of a truly American population and the implications and, more importantly, even the possibility, of successfully transplanting such ideas and populations to American soil and minds.

In effect, questions about what it meant to be "American" tended to focus dramatically on how to incorporate the European heritage, not only of the early colonists, but also of the recent immigrants from all parts of Europe, who had since come to the new land. It is as part of that process, then, that the novel uses several of the tropes current in English literature (but also rooted in early German Romanticism) at the time to convey and allay identity anxieties, to do that "cultural work," which was, to a large extent, the work of defining 
202 Renata R. Mautner Wasserman, Gothic Roots: Brockden Brown's ...

and reinforcing the sense of being a new nation still under siege. Wieland exhibits the common appeal to science as a mysterious form of knowledge that can come dangerously close to being forbidden; it deals in haunted, or apparently haunted places; it probes extreme states of the soul and of consciousness, and it expresses deep distrust of foreign people and religious practices. In the classic English Gothic, for instance, Catholicism provides the locus for evil, often sexual, and of irrationality, greed, and cruelty. In Wieland, it is the German-origin pietism and radical Protestantism that impels the characters to do their evil deeds. ${ }^{8}$ As Sydney J. Krause argues, though Wieland is also subtitled "An American Tale," it is "remarkably German," and "actually anti-German, its ultimate basis resting in Brown's chauvinist Americanness [...] and a reflected antipathy for Otherness." Its distaste for Otherness is no less intense than that of the English Gothic for the Spanish of The Monk, or the Italians of Udolpho, or of both for Catholicism.

The title gives some of this away: Wieland is a German name, and the title character descends from a lesser branch of a German (Saxon) family to which belongs, as we are told, a "modern poet of the same name," Christoph Martin Wieland (6). ${ }^{10}$ We learn of events through the narration of Clara Wieland, with her brother Theodore Wieland, the children of the original immigrant, a believer in one of the more extreme Protestant denominations, accepting no intermediary between himself and the deity. He had established himself along the banks of the Schuylkill, and there organized his property in the style of the European gentry: picturesque, and vaguely agricultural. His New World enterprise had consisted in an attempt to convert Indians to his strict and demanding version of Christianity; he could not hold out in the wilderness or affect its inhabitants, so he returned to the colonial settlements and, occupying the cheap 
land available, and cultivating it with the available slave labor, had become wealthy. In the leisure afforded him by his prosperity, he had dedicated himself to his family and to prayer, the latter taking more and more of his physical and, especially mental energies, and in pursuit of which he had built a "temple" for his daily devotions, at the top of a hill on his property.

At one point, Wieland becomes restless and melancholic; he feels he has a duty toward his God, but is unwilling to perform it: though we are never told what that duty is-probably, in part because Clara cannot bear to envision it and write it, we get hints that it is to follow Abraham in his willingness to sacrifice his son (and the name Brown gave the family may be his way to indicate that, by remanding us to the title of the Wieland work). One night, having gone up to the temple for his devotions, he is suddenly and inexplicably involved in a blaze of fire, and found bludgeoned, his clothes in ashes; he died soon after. The blaze is never explained either by his family or by the text. According to Clara's account (she was six at the time) of her uncle's account, there was "a gleam," her father had suffered "a blow upon his arm," and there was an "explosion," and a "fiery cloud." The uncle is especially credit worthy because "no man's temper is more skeptical," "his belief unalterably attached to natural causes," at which point in the text Brown appends a footnote remanding to one case "exactly parallel" to this, and another, "likewise similar," reported in the Journal de Medicine for February and May 1783, and implying, though not naming, spontaneous combustion, a phenomenon that intrigued people at the time (and turns up in later novels by Dickens, Balzac, and Zola). As far as the reader knows, the burning of the older Wieland may have been a scientifically explainable event, or it may have been divine intervention; the novel never clarifies the matter. As she recounts it, however, Clara asks herself whether this "was 
204 Renata R. Mautner Wasserman, Gothic Roots: Brockden Brown's ...

the penalty for disobedience," hinting, but never saying, what the disobedience would have consisted of (Wieland 17-18). This then, is the first of the mysterious events taking place in the novel. Whatever caused the father's death, Wieland's children and heirs (and we are told precisely how his property was divided, an important fact in any novel, but particularly significant in one that deals with land that, it was said, originally did not "belong" to anyone) appropriate the temple, outfit it with a harpsichord and a bust of Cicero, and turn it from a place to worship a severe and vengeful God, into a site for the pursuit of rational argument and artistic expression, not a place of mysterious lightning, but a dwelling for the Enlightenment that lay at the foundation of the newly independent American Republic.

Wieland's son Theodore, known, throughout the tale, simply as Wieland, in due time comes to the conviction that he needs to finish his father's work, and indeed kills his whole family, in obedience to voices; at the trial, he glows with the sense of accomplishment and shows no guilt.

The Wielands form a small, select society, consisting of the siblings, who love each other dearly, and two friends, Catherine and later Henry Pleyel; the former marries Theodore and the latter is eventually beloved of Clara. They read together, converse, play music, and lead an ideal life of intellectual pursuit and artistic pleasures; their worship is reason and their rituals are friendship. There are interactions with the outside world, mostly implied in small incidents, but these do not intrude in their main activities. And somehow the work of the property gets done, though it is only much later in the novel that there is mention of the "hut" belonging to a couple of employees. Clara has a servant.

Into this society happens a mysterious stranger, Carwin, who exerts an immediate and strong impression on Clara. His garb is 
that of a laborer, but his face is so striking that Clara feels compelled to make a sketch of it and then sits for hours contemplating it. $\mathrm{He}$ becomes a frequent guest at the Wieland gatherings, contributing to their conversations, particularly involved in discussions about the supernatural. Clara shows an interest in him, and is eventually gratified to detect in Pleyel's displeasure a sign of his romantic interest in her. But the next time she sees Pleyel, he berates her bitterly for wantonness, which he says he discovered overhearing a conversation between her and Carwin; he is not specific, but claims she said and confessed things that make her into the kind of woman with whom he cannot have anything to do. She had earlier heard a voice calling to her after she had fallen asleep in a bower where she liked to go for solitude and respite and where she had just dreamt that her brother was luring her into an abyss-the voice tells her to "Hold!" and then enjoins her not to tell anyone of what happened and not to return to the bower. Later, she hears voices in the closet of her room; the second time she hears it, she thinks it is her brother come to do... what? to her; in a show of fortitude, she opens the closet and finds Carwin. Still, she does not think of him in relation to the voices, and suspects the voice in the closet is the same as that of whatever had killed her father; later, she thinks the same voice had suggested to her brother that he should kill his wife and children.

Eventually, in a midnight meeting at her house, that she is very reluctant to grant him, Carwin not only saves her from being killed by her brother, who had escaped from prison and was intent on finishing his job by exterminating that last member of his family, but also confesses to having projected the mysterious voices that everyone had been hearing - the voice that warned Wieland not to go up to the "temple," the voice that told Pleyel his Saxon fiancée was dead, the voice that had warned Clara not to advance to the abyss 
her brother was luring her to in the night, the imitation of Clara's voice that had convinced Pleyel of her unworthiness and caused him to reject her. But he denies having incited Wieland to murder; he confesses to mischief, to trying various psychological experiments, which he admits went wrong and caused pain, but he had not, he says, caused death. Neither does he say anything about the death of Clara's father, though he had discussed its probable causes with the little society of Wielands and Pleyels when he had attached himself to them. As a result, these mysterious and horrific events are never explained in the text, leading to endless speculation among critics and a number of interpretations that circle around questions of historicism and "Gothicism." Christophersen, for one, is firmly on the side of historicism, downplaying the mystery and stressing the ways in which mystery and murder respond to tensions among religious denominations, tensions between more fundamentalist believers and deists, tensions between the English-origin population and the more recent immigrants. Shirley Samuels acknowledges the "Gothic sensationalism" in the novel, but sees it (again) in the service of "contemporary social and political anxiety", this time "about the stability of the family and its freedom from unfaithfulness, often figured as the contamination of the outside world," so that the "lurid" elements, including, in Wieland, incest, repressed desire, and crimes, "encouraged and promoted a conservative, closed model of the family," a configuration that is contradictory in itself, since incest is a horror within the closed family, yet significant as it extrapolates from the literal family to the "family-as nation" $(46,50)$.

However, one of the causes of what Eric Savoy identifies as an American crisis of authority is figured precisely in the fault lines of Clara's account, in its surprising gaps and contradictions. ${ }^{11}$ Although she characterizes herself as rational and strong, she 
shows unaccountable failures of acuity and understanding, almost from the start, when she, at the same time, credits her uncle's testimony about her father's death because he is rational and comes to conclusions only on the basis of empirical evidence, and also speculates on whether her father's death was divine punishment for disobedience. She is strangely perturbed when she first sees Carwin, whom she describes as awkward and rustic (46), his skin pale, his eyes sunken, his hair coarse and straggling, his teeth large and very white, and in "every feature...wide of beauty" (49). But his voice made her drop the cloth she had been holding, and her eyes fill with "unbidden tears," after which she spends hours at her window, contemplating a sketch of him, and half the night awake with thoughts of him; she introduces the episode by stating that his name is connected with "the most turbulent sensations," and she can only describe him with "shuddering reluctance" (45). She does not recognize the nature of her perturbation, and even in retrospect she never names it, even in the veiled way in which the period might allow for recognition of a sexual awakening, doubly barred by gender and class impediments to its recognition, let alone its expression. Tellingly, she transfers the awareness of interest to another object, Pleyel. This and other lapses in insight and logic lead some critics to see her as an unreliable narrator, one lacking in-or avoidingself knowledge. Christophersen notes her refusal to perceive this and other changes that occurred in her and the contradictions that arose in her life, arguing that the "transformation" in the title refers to her. He links that transformation and the blindness to it, directly and allegorically to changes (transformations) that had taken place in America: "Was America prepared to confront herself, or would she seek instead to transform unpalatable self-truths into the platitudes of history?" (38). Bernard Rosenthal declares that Clara is not really 
"the rational person some readers have wanted her to be [...]" (106), which undermines any firm conclusion one might come to about the events in the novel, or their meaning for the characters as well as for the nation.

Nina Baym, however, introduces a different reading altogether, positing that the search for seriousness in the arguments in Brown's novels is misguided, and that as novels they are flawed, showing "carelessness, haste, forgetfulness, and changing intentions [...]" and sacrificing "story line and character [...] for the sake of immediate effect" (88). For Baym, since the story is incoherent at crucial points, and Clara is the narrator and thus the "source of error," it is almost of necessity that Clara be seen an unreliable narrator. The elaborate psychological analysis to which she is subjected is beside the point, since she does not function in the plot, but is only a means for creating "the greatest degree of sensational effect." Baym concludes that "Wieland's superficiality [...] is intentional" and that "[h]oax is its motif" (95). Elizabeth Wall Hinds also finds the novel at its core incoherent: Carwin is "not 'motivated' as a character," and "neither are a good number of events in the novel, most notably the older Wieland's spontaneous combustion;" though she does not impugn Brown's seriousness, she notes that "Wieland does not even 'end' in the usual sense" in that the ending "does not provide a 'key' to the novel as a whole that would unify the preceding chaotic impressions. It simply stops" (120).

This inchoateness, however, can have its own value as a counternarrative to any optimistic and coherent account of its beginnings that the nation craved and strove to produce, in art as well as in history. Thus, whatever anxieties the novel addresses, social, historical, psychological, or even those connected with the very place where the action unfolds-that haven of rationality, the refurbished 
"temple" with its harpsichord and bust of Cicero superimposed on the site of the worship and mysterious combustion of the older Wieland; that land appropriated from the first inhabitants and cultivated by slaves, that house of wealth without work-planted in the American wilderness, these anxieties are very much of the new nation. The continued interest in a novel that is admittedly chaotic in its organization, its development, and its telling, psychologically overwrought, with an unresolved plot, and at least one central character about whose import in the action there are justified doubts, could indicate that it raises particularly troubling questions. While there might be a feeling that a novel that consciously proposes to inaugurate a new national literature should look forward to expected accomplishments in the new nation-and many strive mightily to accomplish this, whether or not they achieve it-this one seems hopelessly caught in imaging the possible ways in which the whole enterprise could go wrong.

Yes, the Old World temples where horrifying sacrifices take place have been refurbished and turned into temples of reason, conversation, and the arts where the classics can be studied and discussed. But the work about which Wieland and Pleyel bandy quotations and syllogisms is an oration where Cicero uses his skills in a case of accusations and counter-accusations of poisoning within a family, and Pleyel argues it is absurd to make "the picture of a single family a model from which to sketch the condition of a nation" (28) almost as a warning against reading the Wielands as representing the new nation-but indirectly acknowledging the impulse to do precisely that. References to Old World history or buildings tend to bring up wars, particularly religious ones, like the Crusades (51) and the religious wars of the seventeenth and eighteenth centuries (35), persecuted religious movements like the aforementioned 
Albigensians and the Camissards $(7,8)$ or the exploits of Jan Zisca, a follower of the Bohemian religious reformer Jan Hus, and the leader of a bloody insurrection against the imperial attempt to re-establish the religious dominion of Rome over the area (71). One could argue that this implies a condemnation of Old World disorder, were it not that the action of Wieland is set shortly after the French and Indian war, which translated European rivalries to the new American lands, and involved its original inhabitants in European political questions, and that the Wieland estate in Pennsylvania is called Mettingen, after a city in northwestern Germany; these are indications that the novel doubts that the separation from the Old World has been, or maybe even can be, accomplished; perhaps it could provide an opening for the establishment of a truly new point of departure; perhaps not.

But these are just the first notes of this discordant New World symphony. Confused by the voices she begins to hear, the narrator, who ought to see the possible order in the encroaching chaos, loses her faith in reason and more and more assumes that what she perceives is a direct intervention of non-human entities in her lifeone hostile and one protective. Those same disembodied voices have Pleyel, against all he knows of Clara by observation and experience, conceive a disgust for her proportionate to his earlier admiration: like other characters, he had described her as almost unnaturally virtuous, reasonable, brave, and intelligent (she was, like her brother, and unlike girls of her time, "instructed in most branches of useful knowledge" and their education was "modeled by no religious standard" $[19,20])$.

Carwin's confession that he himself had produced those voiceshe is a "biloquist," and able to project his voice so it can seem to come from any direction, including from above, as well as imitate any voice he has ever heard-is empirical, like the hint about spontaneous 
combustion, but only a flimsy foundation on which to build the complicated structure of the action. It is, however, enough to save Clara when her brother comes to finish the job he imagines he has been assigned by his Deity: Carwin projects his voice one more time, saving Clara from Wieland, by once more shouting "Hold!" and not letting on where the sound has come from. The confrontation between the siblings ends when Wieland stabs himself to death and collapses in front of Clara, spattering her hand with blood and her mind with guilt both for what she did and what she did not acknowledge about their relation. ${ }^{12}$

Thus in their own disparate ways, the Wieland siblings abandon the rationality on which they had tried to build their lives and run their property, and, lives and property in ruins, put an end to their sojourn in the new world. Wieland is dead, and after recovering from the nervous collapse following those dramatic events, Clara herself moves to Europe, after, as Hinds puts it, having traveled from the "seats of rational activity," the Temple and Mettingen, "toward the uncultivated grounds surrounding Wieland property," and "confronted with the irrational, as if madness within the frontier spaces around her works along with the irrational in experience to destroy her ability to comprehend the phenomena around her" (121). She is writing up her story in retrospect, in Montpellier, as the wife of Pleyel-having come back to the beginning, Montpellier being one of the centers that harbored the Albigensians from which the older Wieland derived his beliefs. Carwin disappears in the American wilderness, an apparent avatar of the restless, inquisitive, and mischievous souls that populate later American fiction, but not one to lay the foundations of an America bent upon wresting itself free from its origins. What remains then is the story, told from afar, and if one attends to Clara's language, with a striking reliance on the 
212 Renata R. Mautner Wasserman, Gothic Roots: Brockden Brown's ...

passive voice and a disconnection from what is happening to her: about opening her heart to Pleyel, she says: "He must not be assured that my heart is his [...]" (72); on sensing someone approaching but not opening her bedroom door, at night, she reports: "The blood once more flowed to my heart and a dawn of exultation began to rise [...]" (91). It is as if she desired nothing more strongly than to distance herself form the events, from her reactions, and from the stage where these were running their course.

Like others of its practitioners, Brown resorted to the Gothic as he tried to deal with the perturbing problems of the world that was building itself around him. However, the Gothic failed him, as much as his characters' rationality failed them. He did not stop writing novels immediately; three other Gothic works pursue the perplexities of his America-Arthur Mervyn and Ormond, set in a plague-ridden city, and Edgar Huntly, in a nightmare forest haunted by spectral Indians (all published in Philadelphia, in 1799). But after two more novels, he stopped writing fiction in 1801, and dedicated himself to translation, to editing the Literary Magazine and American Register, and to writing pamphlets on policy issues, which had occupied him before. As for the national literature, and the Gothic, they went on, more or less pessimistic and problematic, grappling with the necessary incoherence of such a large undertaking as inventing a new nation, sometimes even in a similarly spectacular way.

\section{Notes}

1. Though Brockden Brown is not the very first American novelist, American novels were scarce before he set himself the task of remedying this fault, as he saw it; as David Lee Clarke notes, "Before the appearance of Charles Brocken Brown there were current in America only some four or five native novels, mainly tales of seduction [...]" (155); Brown wrote various fictions, but Wieland was the first of his 
novels to be published in book form, in September of 1798 (Clarke 162). Bill Christophersen notes that "Late-eighteen-century America, aspiring and insecure republic [...] needed to see its own picture and hear its own voice [...]" asserting "its cultural identity [...] and sense of independence from Europe that went beyond matters of sovereignty [...] and expressed itself in the call for a native literature." He singles out Brown as one of the creators of such a literature, since his "fictions are American tales because they revolve psychological, philosophical, moral, and sociopolitical dilemmas central" to America at the time (ix).

2. This view is sufficiently widespread to appear as the first observation in a discussion of how to teach the Gothic to undergraduates, as in Teresa Goddu's contribution to Approaches to Teaching the Gothic of the MLA series: "Historicizing the American Gothic: Charles Brockden Brown's Wieland." I find this collection useful as an index to how the genre is approached for teaching - that is, how a sense of the Gothic, from the eighteenth century to its contemporary flowering, is being conveyed to a generation that is familiar with the idea that Pride and Prejudice can be invaded by zombies.

3. Cottom, 66. Cited in Cannon Schmitt, 117.

4. Peter Kafer, xxi. A number of books on Brown identify his work as "Gothic" in their titles: Kafer's Charles Brockden Brown's Revolution and the Birth of American Gothic, Bill Christophersen's The Apparition in the Glass: Charles Brockden Brown's American Gothic, and Brown is regularly included in essay collections on the Gothic, from the PMLA Approaches to Teaching the Gothic, to Mogen, Sanders, and Karpinski's collection Frontier Gothic, The Cambridge Companion to Gothic Fiction or Frederick S. Frank's gathering of plot summaries in Through the Pale Door: A Guide to and through the American Gothic.

5. Rowland Hughes gives a detailed account of that murder, by James Yates, in 1781, and of the periodicals publications that disseminated and analyzed the news, including a discussion of their reliability.

6. For an extensive discussion of German immigrants and American attitudes toward them, including Brown's, see Sydney J. Krause's "Charles Brockden Brown and the Philadelphia Germans." 
7. Let us remember that Fenimore Cooper's Leatherstocking, hero of American westward expansion and foundational American literature, was brought up by Moravians, who, he claims, taught him his high moral standards.

8. See Christophersen on the presence and importance of followers of German fundamentalist forms of Protestantism, settled particularly in Pennsylvania, as well as on Brown's expressed distrust of religion in general and that form of it in particular.

9. Krause goes on to remark that the novel was published in the year when Congress passed the Alien and Sedition Acts of 1798, aimed at expelling "undesirable foreigners and quelling whatever could be deemed antiAmerican speech;" the anti-German bias is made more visible considering that there was also strong anti-Irish sentiment at the time and that the crime that apparently inspired the most horrific part of the plot was committed by a man with an Irish surname: making the criminal Irish would have been the expected route (86). Germans constituted about one third of the population of Philadelphia in the 1790s, and tended to preserve their language, with a German-language press, and churches that conducted their services in German. They were seen with distrust for siding with the royalists during the Revolutionary wars and were also suspected of trying to introduce the subversive ideas of the French Revolution during Robespierre's Reign of Terror $(89,90,91)$.

10. C. M. Wieland (1773-1813) is the author of The Trial of Abraham, a rendition of the biblical story of Abraham and Isaac, published widely in America in the 1760s and 1770s. See Wieland, Notes, 290.

11. The American Gothic "troubles" the comprehensibility of America as a subject, including the locus of cultural and political authority and the perfectibility of human beings in a democracy (167). Savoy reaches for Lacan's concept of the Real, which he sees as traumatic in an America built on the removal (geographic or biological) of the original inhabitants and the exploitation of slave labor, and Kristeva's "abject" to account for the Gothic element in so much American literature, which reaches for what Freud explains as the "uncanny" (that which "ought to have remained hidden," and that which ought to be familiar but is strange) to deal with anxieties he reads as political but transposed into the psychological realm $(169,170,171)$. Barbara Judson supports her analysis of Brown's works 
and their influence on English poets, particularly Shelley in Prometheus Unbound in part by citing Terry Castle's argument that "it is difficult to avoid the conclusion that it was during the eighteenth century, with its confident rejection of transcendental explanations, compulsive quest for systematic knowledge, and self-conscious valorization of 'reason' over 'superstition, that human beings first experienced that encompassing sense of strangeness and unease Freud finds so characteristic of modern life" (Castle 23). For Judson, as for Savoy, Brown explores the unconscious, and that sense of the uncanny in Wieland (23).

12. Clara dreams that her brother wants to lead her to an abyss; she thinks that he is hiding in her closet to do her harm; they both express perhaps too deep an affection for each other. In any case, there are intimations of incestuous feelings between them-a condition that is not at all alien to the Gothic, and that may in fact be a necessary part of the recipe for a Gothic tale.

\section{References}

Baym, Nina. “A Minority Reading of Wieland.” In Rosenthal, Bernard, ed. Critical Essays on Charles Brockden Brown. Boston: G. K. Hall \& Co., 1981. 87-103.

Brown, Charles Brockden. Arthur Mervyn, or, Memoirs of the year 1793: first and second parts. Edited by Sydney J. Krause and S. W. Reed. Kent, Ohio: Kent State University Press, c2002.

. Edgar Huntly: or, Memoirs of a Sleep-walker. Edited with an introd. by David Lee Clark. New York: Macmillan, 1928.

. Ormond. Edited, with introd., chronology and bibliography by Ernest Marchand. New York: Hafner Publishing Co., 1962.

. Wieland; or The Transformation, an American Tale, and Memoirs of Carwin the Biloquist. [1798] "Introduction" and notes by Emory Elliott. Oxford: Oxford University Press, 1994.

Castle, Terry. The Female Thermometer: Eighteenth-Century Culture an the Invention of the Uncanny. New York: Oxford University Press, 1995.

Christophersen, Bill. The Apparition in the Glass: Charles Brockden Brown's American Gothic. Athens: The University of Georgia Press, 1993. 
Clark, David Lee. Charles Brockden Brown, Pioneer Voice of America. Durham, NC: Duke University Press, 1952.

Cottom, Daniel. The Civilized Imagination: A Study of Ann Radcliffe, Jane Austen, and Sir Walter Scott. Cambridge: Cambridge University Press, 1985.

Frank, Frederick S. Through the Pale Door: A guide to and through the American Gothic. Westport, CT: Greenwood Press, 1990.

Goddu, Teresa A. "Historicizing the American Gothic: Charles Brockden Brown's Wieland." In Hoeveler, Diane Long, and Tamar Heller, eds. Approaches to Teaching Gothic Fiction: The British and American Traditions. New York: The Modern Language Association, 2003. 18489.

Hoeveler, Diane Long, and Tamar Heller, eds. Approaches to Teaching Gothic Fiction: The British and American Traditions. New York: The Modern Language Association, 2003.

Hogle, Jerrold E., ed. The Cambridge Companion to Gothic Fiction. Cambridge: Cambridge University Press, 2002.

Hughes, Rowland. ''Wonderfully Cruel Proceedings:' The Murderous Case of James Yates." Canadian Review of American Studies. 38.1 (2008): 43-62.

Judson, Barbara. "A Sound of Voices: The Ventriloquist Uncanny in Wieland and Prometheus Unbound." Eighteenth-Century Studies. 44.1 (Fall 2010): 21-37.

Hinds, Elizabeth Jane Wall. "Brown and the Frontiers of Discourse." In Mogen, David, Scott P. Sanders, Joanne B. Karpinski, eds. Frontier Gothic: Terror and Wonder at the Frontier in American Literature. Cranbury, NJ: Associated University Presses, 1993. 109-125.

Kafer, Peter. Charles Brockden Brown's Revolution and the Birth of American Gothic. Philadelphia: University of Pennsylvania Press, 2004.

Krause, Sydney J.. "Charles Brockden Brown and the Philadelphia Germans." Early American Literature. 39, 1 (2004): 85-119.

Mogen, David, Scott P. Sanders, Joanne B. Karpinski, eds. Frontier Gothic: Terror and Wonder at the Frontier in American Literature. Cranbury, NJ: Associated University Presses, 1993. 
Rosenthal, Bernard, ed. Critical Essays on Charles Brockden Brown. Boston: G. K. Hall \& Co., 1981.

Rosenthal, Bernard. "The Voices of Wieland." In Rosenthal, Bernard, ed. Critical Essays on Charles Brockden Brown. Boston: G. K. Hall \& Co., 1981. 104-125.

Samuels, Shirley. "Wieland: Alien and Infidel." Early American Literature. 25.1 (1990): 46-66.

Savoy, Eric. "The Rise of American Gothic." In Jerrold E. Hogle, ed. The Cambridge Companion to Gothic Fiction. Cambridge: Cambridge University Press, 2002. I67-187.

Schmitt, Cannon. "Suffering Through the Gothic: Teaching Radcliffe." In Hoeveler, Diane Long, and Tamar Heller, eds. Approaches to Teaching Gothic Fiction: The British and American Traditions. New York: The Modern Language Association, 2003. 115-121.

Simpkins, Scott. "Teaching the Male Gothic: Lewis, Beckford, and Stevenson." In Hoeveler, Diane Long, and Tamar Heller, eds. Approaches to Teaching Gothic Fiction: The British and American Traditions. New York: The Modern Language Association, 2003. 122-126.

Tompkins, Jane. Sensational Designs: The Cultural Work of American Fiction, 1790-1860. New York: Oxford University Press, 1985.

[Received in 18/01/2012. Approved in 22/05/2012] 
